\title{
KIERUNKI WSPÓŁCZESNEJ HERMENEUTYKI TEOLOGICZNEJ
}

Terminem „hermeneutyka” (pochodzącym od greckiego słowa hermenéuein, tzn. tłumaczyć, wyjaśniać, obwieszczać) określa się dość powszechnie naukę o zasadach interpretacji, czyli rozumienia i wyjaśniania tekstów nie dość jasnych co do swej treści i swojego sensu. Często też używało się i używa się dotychczas tego terminu w znaczeniu samego procesu interpretacji takich tekstów, a więc zamiennie $z$ terminem „egzegeza", wzgl. „komentowanie”, czy wyjaśnianie ${ }^{1}$.

W nauce kościelnej wypracowywano w ciągu wieków, od zarania chrześcijaństwa począwszy, tylko hermeneutykę biblijną, czyli zasady interpretacji tekstów Pisma św. Starego i Nowego Testamentu. Obecnie, po soborze Watykańskim II, w związku z aktualnością sprawy reinterpretacji dogmatów, wzgl. orzeczeń kościelnych oraz artykułów wiary, zachodzi potrzeba dokładniejszego wypracowania zasad rozumienia i wykładni również owych orzeczeń, czy artykułów zawartych w Symbolach wiary. $\mathrm{Na}$ razie stosuje się tu analogiczną metodę interpretacji jak $\mathrm{w}$ interpretacji Biblii.

Dlatego też przez określenie „hermeneutyka teologiczna”, użyte w tytule referatu ${ }^{2}$, należy rozumieć zasady interpretacji zarówno tekstów

1 Terminem ,hermeneutyka” zaczęli posługiwać się najpierw autorzy protestancey w 17-ym, a następnie katoliccy w 18-tym wieku; przedtem było w użyciu określenie ,ars interpretandi". W pojmowaniu celu i natury hermeneutyki przesunięto od czasów F. Schleiermachera $i$ W. Diltheya akcent $z$ w y jaśn i e n i a (filologicznego, historycznego, filozoficznego i teologicznego) danego tekstu na rozumienie wyrażonych w tekście myśli, intencji, czy doświadczeń autora oraz właściwego sensu tekstu (rzeczowego, czy egzystencjalnego); por. J. M. Robinson, Dic Hermeneutik seit Karl Barth, w Neuland in der Theologie (=Neuland), t. II: Die neue Hermeneutik, Zürich 1965, 36-40 i 61-108; P. Grech, Gesù storico e ermeneutica esistenziale, Roma 1973, 58-60.

2 Referat ten wygłoszony w czasie sympozjum, o którym mowa na wstępie, uległ przed oddaniem tekstu do druku pewnej modyfikacji. 
biblijnych, jak i wszelkich definicji oraz twierdzeń z dziedziny wiary. Bo zresztą te definicje i twierdzenia o tyle tylko są prawowite, o ile harmonizują co do swej treści i sensu z treścią i sensem słowa Objawienia Bożego, zawartego w Biblii.

Problem hermeneutyczny stał się ostatnio nie tylko bardzo aktualnym, ale wprost kluczowym i centralnym zagadnieniem $\mathrm{w}$ teologii zarówno protestanckiej jak i katolickiej ${ }^{3}$. A również w takich naukach świeckich jak: filozofia języka, wzgl. mowy ludzkiej, religioznawstwo, historia czy historiozofia itp. Zagadnieniem hermeneutyki teologicznej czy filozoficznej zajmują się różne kongresy i sympozja naukowe. A rezultaty intensywnych dociekań i badań, żywych dyskusji i kontrowersji wyrażają się w całej lawinie różnych mniej lub więcej oryginalnych i ciekawych rozpraw ${ }^{4}$.

Zadaniem moim jest omówienie niektórych tylko głośniejszych koncepcji wyznaczających kierunki współczesnej hermeneutyki teologicznej. Pominięte będą natomiast uwagi o kierunkach tradycyjnych, a więc tak o ogólnie przyjętej dziś w katolicyzmie teorii hermeneutycznej (rozwiniętej szczególnie w ostatnim 30-leciu, w związku z encykliką Piusa XII „Divino afflante Spiritu” oraz Konstytucją soboru Watykańskiego II „Dei Verbum") — jak i o tradycyjnej dla protestantyzmu historyczno-krytycznej hermeneutyce o różnych odcieniach.

Najpierw będzie mowa o kierunku hermeneutyki, którą można by nazwać sekularyzacyjną, a następnie o kilku nurtach hermeneutyki nawiązujących do założeń filozofii egzystencjalnej.

\section{HERMENEUTYKA SEKULARYZACYJNA}

Problem hermeneutyczny związany jest ściśle z zagadnieniem natury, funkcji i sensu języka, wzgl. mowy ludzkiej. Już starożytni przedchrześcijańscy filozofowie, jak np. Platon i Arystoteles, snuli refleksje nad językiem. Wypowiadali przy tym ciekawe uwagi na temat charakteru i znaczenia wypowiedzi o boskiej rzeczywistości transcendentnej, czyli można by powiedzieć - na temat języka religijno-teologicznego. Zdając sobie dobrze sprawę z tego, że język religijny nie może wyrazić adekwatnie boskiej rzeczywistości, że przy wypowiedziach religijnych chodzi raczej o pewne negacje niż o afirmacje, o przenośnie, symbole, czy analo-

3 Por. René Marlé, Le problème théologique de l’herméneutique, Paris ${ }^{21968,9}$; R. Lapointe, Panorama de l'herméneutique actuelle, w: „Bulletin de théologie biblique", 2 (1972) $107 \mathrm{n}$.

4 Por. N. Henrichs, Bibliographie der Hermeneutik, Düsseldorf 1972; R. Lapointe w art. cyt. przytacza ponad 130 nowszych prac dotyczących problemu hermeneutycznego. 
giczne tylko pojęcia - widzieli ci filozofowie konieczność odpowiedniej interpretacji (hermeneia) takich wypowiedzi ${ }^{5}$.

W ostatnim ćwierćwieczu zagadnienie języka, wzgl. mowy ludzkiej stało się przedmiotem niezwykle intensywnych dociekań i ożywionych dyskusji już nie tylko w kołach filologów, czy etnologów, ale równiez: teoretyków antropologii filozoficznej oraz teologów ${ }^{6}$. I właśnie w związku z nowopowstałymi systemami, czy koncepcjami filozofii lingwistycznej: pozytywizmu logicznego, analizy językowej, czy egzystencjalizmu, problem hermeneutyczny nabrał nadzwyczajnej aktualności.

Radykalną koncepcją, gdy chodzi o metodę interpretacji kerygmatu chrześcijańskiego, jest koncepcja nawiązująca do tezy pozytywizmu logicznego, którego inicjatorem był L. Wittgenstein wcześniejszy, a głównym teoretykiem i propagatorem $\mathrm{R}$. Carnap. Chodzi mianowicie o założenie, że teoretyczne znaczenie mają tylko pojęcia i zdania naukowe, których treść jest empirycznie stwierdzalna; a ponieważ pojęcia i zdania z zakresu metafizyki oraz teologii nie są w ten sposób stwierdzalne co do swej treści, więc nie mają one żadnego teoretycznego znaczenia, są bez sensu 7. Odwołując się do tego założenia oraz do rzekomego faktu całkowitej niezrozumiałości języka religijnego dla współczesnych ludzi, znani teologowie ,śmierci Boga” (W. Hamilton, T. J. Altizer, P. Van Buren, H. Cox, L. Devart) postulują świecką interpretację chrystianizmu ${ }^{8}$.

Czołowy przedstawiciel tego kierunku, teolog holenderski, Paul Van Buren stwierdza wyraźnie w swym dziele ,The secular meaning of the Gospel" (New York 1963), że tradycyjny język teologiczny pozbawiony jest sensu i stara się wykazać, że jedynie słuszną interpretacją Ewangelii jest interpretacja świecka. Wypowiedzi wiary winny, jego zdaniem, być rozumiane tylko jako wypowiedzi, które opisują i zalecają szczególny sposób widzenia świata na wzór Jezusa oraz wyzwalający sposób życia, dostosowany do takiej wizji ${ }^{9}$.

Do poglądu Van Burena i innych teologów ,śmierci Boga” odnośnie do zasad i metody interpretacji pojęć i wierzeń chrześcijańskich, opartych na wypowiedziach Pisma św., zbliżone są mniej lub więcej zapatrywania niektórych zwolenników analizy językowej, rekrutujących się przeważnie spośród teologów anglosaskich i amerykańskich ${ }^{10}$.

Bardzo głośnym echem odbiły się w całym świecie tezy o sekularyzacyjnej interpretacji chrystianizmu niemieckiego teologa Dietricha Bon-

5 Por. B. Mondin, Il problema del linguagio teologico dalle origini ad oggi, Brescia $1971,13-32$.

6 Por. tamże, 439; omawiając różne nowoczesne systemy filozofii lingwistycznej, cytuje Mondin wielką ilość różnojęzycznych studiów z tego zakresu.

7 Por. tamże, $441-445$.

8 Por. tamże, 421-426.

s Por. tamże, 423 .

10 Por. tamże, 446-460. 
hoeffera (straconego w r. 1945 za udział w spisku antyhitlerowskim) ${ }^{11}$, jak również biskupa anglikańskiego, Johna Robinsona, autora głośnego dzieła ,Honest to God" (London 1963) ${ }^{12}$.

Również teologowie „nadziei” (J. Moltmann, W. Pannenberg, J. Metz, E. Schillebeeckx) - choć nie odmawiają wszelkiego znaczenia tradycyjnemu językowi teologicznemu - opowiadają się jednak za możliwością i potrzebą świeckiej interpretacji orędzia chrześcijańskiego ${ }^{13}$.

\section{HERMENEUTYKA EGZYSTENCJALNA R. BULTMANNA}

Przemożny wpływ, jaki filozofia egzystencjalna, zwłaszcza w ujęciu M. Heideggera, wywarła i wciąż wywiera na umysłowość współczesną, zaznaczył się też wyraźnie w dziedzinie teologii chrześcijańskiej, a szczególnie teologii protestanckiej. Dotyczy on w pierwszym rzędzie kwestii metody interpretacji depozytu Objawienia.

Teologiem, który jako pierwszy opracował koncepcję heremeneutyki biblijno-teologicznej w ścisłym oparciu o założenia antropologiczne M. Heideggera był — jak wiadomo - głośny myśliciel niemiecki Rudolf Bultman 14. W początkach swej kariery naukowej sprzyjał on w swoich pracach egzegetycznych historyczno-krytycznej metodzie interpretacji Pisma św., stosowanej w egzegezie kół liberalnych. Akcentował przy tym szczególnie ,historię form” (Formgeschichte), o której rozprawiał szeroko w swej rozprawie habilitacyjnej, pt. Geschichte der synoptischen Tradition (Göttingen 1921). Ale nie mógł pogodzić się z wnioskami teologii liberalnej. Czynił jej zarzut, iż sprzyja pewnego rodzaju ,,panhistoryzmowi", że nie widzi względności rezultatów wiedzy ludzkiej i popada w złudzenie, zakładając, iż można dosięgnąć wprost świat wiary. Opowiadał się raczej za podstawowymi tezami nowego, ,rewolucyjnego” kierunku teologicznego, a mianowicie teologii dialektycznej Karola Bartha, który kładł nacisk na konieczność wierzącej postawy hermeneuty (teologa), jego otwartość duchową i gotowość dania posłuchu słowu Bożemu, utajonemu pod osłoną natchnionych tekstów biblijnych, jego wysiłek, aby przy in-

11 Por. tamże, 413-420.

12 Por. tamże, 421 n.

13 Por. tamże, 421 n. i 426 n. oraz osobną rozprawę tegoż autora pt. I teologi della speranza, Torino 1970.

14 Główne rozprawy Bultmanna na temat zagadnienia hermeneutyki zamieszczone w zbiorowym wydaniu pt. Glauben und Verstehen $(=G V)$ są następujące: Welchen Sinn hat es von Gott zu reden, w: t. I (Tübingen $\left.{ }^{6} 1966\right), 26-37$; Das Problem der Hermeneutik, w: t. II (Tübingen 41965), 211-235; Ist voraussetzunglose Exegese möglich?, w: t. III (Tübingen $\left.{ }^{3} 1965\right), 142-150 ;$ Zum Problem der Entmythologisierung, w: t. IV (Tübingen 1965), 128-137; Jesus Christus und die Mythologie, w: t. IV, 141-189; poza tym w: Kerygma und Mythos (= KM), t. I (Hamburg ${ }^{\overline{1}} 1967$ ), 15-48: Neues Testament und Mythologie. 
terpretacji tych tekstów dotrzeć do ducha (Geist) i do „rzeczy” (Sache) Biblii ${ }^{15}$.

Ale, chociaż R. Bultmann odniósł się $\mathrm{z}$ wielkim uznaniem do zasadniczej intuicji K. Bartha, nie aprobował jednak w całości metody her.meneutycznej, zastosowanej przez niego w głośnym komentarzu do Listu do Rzymian i przedstawionej krótko w przedmowie do drugiego wydania tego Komentarza (,Der Römerbrief”, Bern ${ }^{21922)}{ }^{16}$. Owszem, poddał tę metodę dość surowej krytyce, zarzucając Barthowi wręcz błędne rozumienie ,rzeczy” Listu do Rzymian, skutkiem nie dość krytycznego stanowiska wobec tekstu Pawłowego, trzymania się literalnego sensu sformułowań Apostoła ${ }^{17}$.

Idea radykalnej ,demitologizacji” tekstów biblijnych oraz uwydatniania ich sensu egzystencjalnego, jako najgłębszego i najistotniejszego, opanowywała już w owym czasie coraz silniej umysł Bultmanna. Przyczyniło się do tego studium „ojca nowoczesnej hermeneutyki”, F.D.E. Schleiermachera, jego ucznia W. Ditheya ${ }^{18}$, a jeszcze w większym stopniu zapoznanie się bliższe z założeniami filozofii egzystencjalnej M. Heideggera, wyłożonymi w jego dziele „Sein und Zeit” (Halle 1927). Analiza antropologiczna tego autora ${ }^{19}$ przypadła Bultmannowi bardzo do gustu. Podzielił całkowicie jego pogląd na strukturę ludzkiego bytu, jako bytu „historycznego" (Dasein), jako egzystencji (Existenz) „historycznej” oraz na problem ludzkiego ,rozumienia” rzeczywistości (Verstehen). Podzielił też tezę Heideggera (idącego tu za Schleiermacherem i Diltheyem) o decydującej roli nastawienia i zaangażowania osobistego hermeneuty w procesie interpretacji danego tekstu: jego „otwartości”, pewnego ,,przedrozumienia” rzeczy, o której tekst mówi, aby mógł zadawać temı tekstowi stosowne pytania i dialogować z nim (circulus hermeneuticus) oraz o jego gotowości na decyzję egzystencjalną.

W rozprawie pt. „Jesus Christus und die Mytholog i e" 20 stwierdza nasz autor wyraźnie, iż filozofia egzystencjalna daje

15 O stosunku swym do teologii liberalnej oraz do teologii dialektycznej pisze B. w rozprawach: Die liberale Theologie und die jüngste theologische Bewegung (w GV, t. I, 1-15) oraz Die Bedeutung der 'dialektischen Theologie' für die neutestamentiche Wissenschaft (w GV, t. I, 114-133); por. téz R. Marlé, dz. cyt., 24-36.

${ }_{16}$ R. Marlé uważa zasady hermeneutyczne podane przez Bartha za ,prawdziwy punkt wyjścia współczesnych refleksji nad hermeneutyką"; por. dz. cyt., 24; H. G. Gadamer nazwał Römerbrief manifestem hermeneutycznym; por. J. M. Robinson, Neuland, t. II, 39 przyp. 62.

17 Por. R. Marlé, dz. cyt., $32-36$.

18 Na autorów tych, zwł. na Diltheya powołuje się Bultmann często, np. w rozprawie Das Problem der Hermeneutik (GV, t. II, 211-235).

${ }_{19}$ Bardzo zwięzłe, ale należycie informujące uwagi o założeniach hermeneutycznych Heideggera podaje Fr. Mussner w pracy: Geschichte der Hermeneutik von Schleiermacher bis zur Gegenwart, w: Handbuch der Dogmengeschichte, t. I, fasc. 3c, cz. $2,9-11$.

20 Por. GV, t. IV, 169-172 oraz GV, t. II, 232. 
stosowne narzędzie dla hermeneutyki biblijnej, bo przedmiotem badania tej filozofii jest egzystencja ludzka, a przy interpretacji Biblii mamy właśnie pytać o rozumienie w niej egzystencji ludzkiej. Analiza egzystencjalna dostarcza odpowiednich ,pojęć, za pomocą których można adekwatnie mówić o egzystencji ludzkiej", można zadawać tekstom biblijnym stosowne pytania dotyczące egzystencji. Bo analiza ta tłumaczy należycie strukturę bytu ludzkiego: wskazuje na różnicę zachodzącą między bytem człowieka, jako egzystencją, a bytem wszelkich innych stworzeń, które tylko istnieją, ale nie „egzystują”. Tylko bowiem człowiek może realizować odpowiedzialnie samego siebie, swoją egzystencję, mając świadomość siebie i zdolność do podejmowania w konkretnych sytuacjach, w których się znajduje, decyzji egzystencjalnych. Człowiek tylko jest bytem „historycznym” (geschichtlich), bytem „możności”, mającym własną historię; jego teraźniejszość pochodzi z jego przeszłości i kieruje się ku przyszłości. Człowiek - zauważa autor na innym miejscu za Heideggerem - posiada możność bycia tym, czym nie jest. W decyzjach egzystencjalnych, „,w działaniu zdobywa prawdziwą możność swego bytu" 21.

Podzielając stanowisko Heideggera w sprawie natury człowieka, jako egzystencji „historycznej”, realizującej się w działaniu, poprzez łańcuch decyzji podejmowanych hic et nunc, w konkretnych sytuacjach życiowych - opowiada się Bultmann zdecydowanie za egzystencjalną hermeneutyką biblijno-teologiczną. Jego zdaniem, należy przy interpretacji danych tekstów biblijnych, czy artykułów wiary starać się głównie o zrozumienie i wyjaśnienie ich sensu egzystencjalnego, jako najgłębszego i najistotniejszego. „Biblię - pisze on - mamy interpretować nie tylko jako dokument historyczny, dla ustalenia pewnych faktów historycznych, ale przede wszystkim jako dokument, który ma nam powiedzieć coś o tym, jak ma się sprawa z naszym życiem i naszą duszą w dzisiejszej sytuacji" ${ }^{22}$. To nie obiektywną treść pojęć zakładanych w Nowym Testamencie należy badać $w$ nowotestamentowej mitologii, lecz rozumienie egzystencji, które się poprzez te pojęcia wyraża" ${ }^{23}$.

Autor nasz jest przekonany, że poprzez odpowiednie zastosowanie przy interpretacji tekstów Pisma św. ustaleń analizy egzystencjalnej można odkryć i wyrazić prawdziwy i ostateczny sens tych tekstów; że oparta na tej analizie egzystencjalna interpretacja ,nadaje się do prowokowania decyzji, do zaangażowania, ponieważ przywraca słowu Bożemu jego charakter interpelacji" ${ }^{24}$.

\footnotetext{
21 Por. GV, t. I, 118 i t. IV, 129-131.

22 Por. GV, t. IV, 22.

23 Por. $K M$, t. I, 22.

24 Por. tamże, 23.
} 
Warunkiem rozumienia egzystencjalnego sensu tekstów biblijnych jest - według Bultmanna - ich demitologizacja i nawiązanie z nimi egzystencjalnego kontaktu, stawianie im określonych pytań dotyczących istotnej „rzeczy”, o której mówią. A zaś stawianie takich pytań i dialogowanie $z$ tekstem suponuje z konieczności pewne ,przedrozumienie” tej istotnej ,rzeczy” danego tekstu (które jest możliwe, bo wynika z życio-wego związku i naszego stosunku do ,rzeczy” orędzia biblijnego). Bez tego ,przedrozumienia” niemożliwe byłoby należyte stawianie pytań tekstowi biblijnemu i dialogowanie z nim, a konsekwentnie niemożliwe byłoby też jasne zrozumienie jego egzystencjalnego sensu i decyzja wiary, czyli realizowanie się wydarzenia zbawczego (Heilsgescheben) ${ }^{25}$.

W związku z zarzutem (ze strony $\mathrm{m}$. in. Bartha), iż człowiek, jako stworzenie skończone, nie może mieć przecież bez objawienia żadnego „,przedrozumienia” Boskiej rzeczywistości — tłumaczy nasz autor, że nie chodzi tu o jakąś wiedzę rozumową, lecz o wiedzę egzystencjalną. ,W człowieku - pisze on - żywotna jest egzystencjalna wiedza o Bogu, jako pytanie o szczęście, o zbawienie, o sens świata i historii, o właści.wość jego własnego bytu” ${ }^{26}$. „Człowiek - zaznacza na innym miejscu wie coś z góry o Bogu... Ma on stosunek do Boga w swym szukaniu Boga świadomym lub nieświadomym. Życie człowieka jest poruszane przez szukanie Boga bo jest ono poruszane zawsze świadomie lub nieświadomie pytaniem o swą własną egzystencję... Pytanie o Boga i pytanie o mnie samego są identyczne" ${ }^{27}$. Tłumacząc rzecz w ten sposób odwołuje się Bultmann do słów św. Augustyna z "Confessiones” (ks. I r. 1): „Tu nos fecisti ad $\mathrm{Te}$, et cor nostrum inquietum est, donec requiescat in Te".

W związku z postulowaniem ,demitologizacji” przy interpretacji tekstów Pisma św. wyjaśnia niemiecki teolog, że ,mity nadają rzeczywistości transcendentnej obiektywność immanentną, światową", że jako mitologiczny należy rozumieć ,taki sposób przedstawiania, w którym to, co nie jest ze świata, to znaczy boskość, ukazana jest jako będąca ze świata, jako ludzka; zaświaty ukazane są jako świat ziemski" ${ }^{28}$. Biblia

25 Por. GV, t. II, 216-218 i 230-233, t. IV, 166-168 oraz osobną rozprawę Bultmanna pt. Ist voraussetzunglose Exegese möglich?, w której autor podaje 5 zasad hermeneutycznych dla egzegezy Pisma św.: ,1) Die Exegese der biblischen Schriften muss wie jede Interpretation eines Textes vorurteilslos sein; 2) Die Exegese ist aber nicht voraussetzungslos, weil die historische Interpretation die Methode historisch-kritischer Forschung voraussetzt; 3) Vorausgesetzt ist ferner der Lebenszusammenhang des Exegeten mit der Sache, um die es in der Bibel geht, und damit Vorverständnis; 4) Das Vorverständnis ist kein abgeschlossenes, sondern offenes, so dass es zur existiellen Begegnung mit dem Text kommen kann und zu existentiellen Entscheidung; 5) Das Vorverständnis des Textes ist nie ein definitives, sondern bleibt offen, weil der Sinn der Schrift sich in jede Zeit neu erschliesst"; por. GV, t. III, $148 \mathrm{n}$.

26 Por. GV, t. II, 232.

27 Por. GV, t. IV, 168.

28 Por. KM, t. I, 22. 
właśnie podaje — jego zdaniem — mitologiczny obraz świata; daje wyraz mitologicznemu rozumieniu świata, historii oraz egzystencji ludzkiej. Mitologiczne bowiem są w niej wyobrażenia o ingerencji sił nadprzyrodzonych $w$ bieg spraw ziemskich. Mitologiczne jest też przedstawienie wydarzeń zbawczych, stanowiących właściwą treść orędzia nowotestamentowego ${ }^{29}$.

Otóż człowiek współczesny nie może - zdaniem Bultmanna - zgodzić się na przyjęcie mitologicznego obrazu świata, podanego w Biblii. Dzisiejszy naukowy obraz świata i historii nie zna nadprzyrodzonej ingerencji Boga czy złego ducha w bieg wydarzeń ziemskich, lecz tylko siły i prawa natury. Toteż chrystianizm w ujęciu mitologicznym jest dla współczesnego człowieka zupełnie niewiarygodny ${ }^{30}$.

Trzeba więc - zdaniem naszego autora - odmitologizować orędzie nowotestamentowe, aby ludzie współcześni mogli w tym orędziu doświadczyć wezwania Bożego, skierowanego do siebie. Trzeba odrzucić wyobrażenia mitologiczne, uwolnić słowo Boże od przedawnionego obrazu świata. „Metoda odmitologizowania polega na odrzuceniu obrazów mitologicznych, a zachowaniu głębszego znaczenia ukrytego w nich" ${ }^{31}$. Nowy Testament nie ma przecież na celu przekazania nam jakiegoś „obrazu świata", lecz zmierza do tego, by ludzie mogli usłyszeć wezwanie (Ruí) słowa Bożego. Słowo Boże w Piśmie św. wzywa człowieka ku Bogu, który jest poza światem i poza naturalnym myśleniem naukowym. Przywołuje go ono do jego prawdziwego ,,ja”, do jego prawdziwej osobowej egzystencji, która również pozostaje poza widzialnym światem i poza racjonalnym myśleniem. Słowo Boże apeluje do człowieka w jego osobowej egzystencji i wyzwala go tym samym od niego samego, od świata, od troski i trwogi, które go łamią, skoro tylko zapomina o zaświatach ( $\mathrm{Je}$ nseits). Słowo Boże wzywa człowieka ku prawdziwej wolności... a zadanie demitologizacji nie posiada żadnego innego celu, jak uwyraźnienie wezwania słowa Bożego ${ }^{32}$. „Dopiero demitologizacja czyni wyraźnym znaczenie tajemnicy Boga, którą wiara jest zainteresowana, a mianowicie nie to, czym Bóg jest sam $\mathrm{w}$ sobie lecz jak postępuje on $\mathrm{z}$ człowiekiem. Jest to tajemnica nie dla teoretycznego myślenia lecz dla naturalnych pragnień i pożądań człowieka" 33 .

Oto w szkicowym zarysie koncepcja hermeneutyki biblijno-teologicznej Bultmanna, której zasady stosuje on konsekwentnie w swoich przedziwnych nieraz wywodach teologicznych. Koncepcja ta napotkała, gdy chodzi o niektóre jej aspekty, zwłaszcza postulat radykalnej demitolo-

29 Por. tamże, 15-17; GV, t. IV, 143-148.

30 Por. tamże.

31 Por. GV, t. IV, 146.

32 Por. tamże, 159.

33 Por. tamże, 162. 
gizacji oraz tezę o ,przedrozumieniu” istotnej, ,rzeczy" Biblii, na negatywną ocenę zarówno wielu teologów katolickich, jak i szeregu wybitnych autorów protestanckich (np. K. Bartha ${ }^{34}$ i O. Cullmanna ${ }^{35}$ ).

Ale oprócz licznych krytyków i przeciwników znalazła też koncepcja Bultmanna wielu gorących zwolenników i naśladowców wśród uczonych protestanckich. A również u teologów katolickich niektóre jej aspekty spotkały się z uznaniem (o czym jeszcze będzie poniżej mowa).

\section{3. „NOWA HERMENEUTYKA”}

Na koncepcji Bultmanna wzorują się przede wszystkim dwaj czołowi przedstawiciele tzw. ,nowej hermeneutyki” i ,nowej teologii”: Gerard Ebeling i Ernest Fuchs. Obydwaj ci teologowie idą jeszcze dalej niż ich mistrz, snując w oparciu o filozofię lingwistyczną M. Heideggera późniejszego oraz H. G. Gadamera spekulacje często zawiłe i niejasne (zwł. Fuchs) na temat natury i funkcji słowa Bożego, ukrytego pod osłoną ludzkich, mitologicznych rzekomo tekstów Biblii. Niepodobna streszczać tu dokładnie ich wywodów. Ograniczę się więc tylko do ich bardziej zasadniczych twierdzeń.

\section{A. Poglądy G. Ebelinga}

Profesor teologii i kierownik Instytutu hermeneutycznego w Zürichu, Gerard Ebeling stara się wykazać w swej rozprawie „Wort Gottes und Hermeneutik" ${ }^{36}$, że hermeneutyka teologiczna, jako teoria rozumienia kerygmatu chrześcijańskiego, jest n a u k ą o sło w i e B oż y m (Lehre vom Wort Gottes) ${ }^{37}$, które jest źródłem rozumienia teologicznego. Celem hermeneutyki — według tego autora - jest sprawienie, aby słowo przeszłe, utrwalone w dokumencie, stało się aktualnym, orientującym praktycznie ku przyszłości, czyli aby stało się ono rzeczywiście słowem, odnajdując w ten sposób swój sens.

Słowo ludzkie w ogólności uważa on, podobnie jak Heidegger póź: niejszy i Gadamer, za miejsce wyrażania się egzystencji ludzkiej oraz za centralny punkt wyjścia dla rozumienia całej rzeczywistości świata. Słowo jest czymś więcej niż przekazem pewnego zasobu idei. Ono ,,wskazuje zawsze jakiś sens, tj. orientuje skutecznie do jakiegoś celu, wywołuje rzeczywistość, powodując jej nadejście, komunikując ją, dając w niej uczestnictwo" 38 .

34 Por. jego rozprawę: Rudolph Bultmann. Ein Versuch ihn verstehen?, Zürich 1953.

3. Por. Le salut dans l'histoire, Neuchâtel 1966.

36 Por. wyd. zbior. jego prac pt. Wort und Glaube (=WG), Tübingen ${ }^{31967}$, $314-346$.

37 Por. WG, 338 i 348.

38 Por. R. Marlé, dz. cyt., 75-78.

Analecta -22 
Słowo Boże nie różni się co do swej istoty od zwyczajnego słowa ludzkiego; nie jest ono słowem nadrzędnym, nadprzyrodzonym. Różnica mię-dzy słowem Bożym a słowem ludzkim wyraża się tylko w tym, że słowo Boże jest słowem w pełnym znaczeniu tego wyrazu, słowem, w którym i przez które wszelkie słowo ma swe dopełnienie i swój sens. Samo tylko słowo Boże ma moc doprowadzić wszelką rzeczywistość do jej celu, nadać każdej rzeczy prawdziwy, ostateczny sens. Ono to jest afirmacją i dopełnieniem zarazem ( $Z u$-sage ${ }^{39}$. Człowieka pogrążonego w kłamstwie, w iluzjach i ciemnościach, dla którego świat jest bezsensem, a własna egzystencja bez przyszłości, skazana na śmierć, słowo Boże usłyszane i przyjęte wyzwala spod prawa próżnej samowystarczalności, a otwiera przed nim nieskończony świat obietnic. Dzięki mocy słowa Bożego, wy.zwalającej i oświecającej egzystencję człowieka i wszystko inne z nią, człowiek zdolny jest ze swej strony do prawdziwego autentycznego słowa, tj. słowa wiary, które stanowi odpowiedź (Ant-Wort) na słowo Boże. I w tym słowie wiary, które jedynie otwiera na nieskończoną przyszłość, realizuje się prawdziwa egzystencja, prawdziwe człowieczeństwo. A ta realizacja człowieczeństwa nie uskutecznia się w jakiejś sferze eterycznej, czy w zaciszu życia czysto wewnętrznego lecz wśród ludzi i realnego świata naszych doświadczeń i naszego działania. Świat jest właśnie miejscem egzystencji ludzkiej... Słowo wiary wzniecone przez słowo Boże jest dopełnieniem słowa ludzkiego, w którym cała rzeczywistość odnajduje swój sens ${ }^{40}$.

W świetle powyższych założeń stara się Ebeling naświetlić bliżej problem hermeneutyczny, który uważa za problem par excellence teologiczny. Zaznacza tu najpierw, że już Reformacja wskazała podstawową zasadę hermeneutyczną przez dewizę sola Scriptura, z którą równoznaczna jest w praktyce teza Lutra, iż Pismo św. jest sui ipsius interpres (czyli że nie potrzeba tradycji dla jego rozumienia). Ale na razie ortodoksja protestancka nie zrozumiała tego należycie. Niesłuszne identyfikowanie słowa Bożego z Pismem św., traktowanie tego słowa niezależnie od jego aktualizacji i uczynienie z Pisma św. statycznej reguły wiary - przeszkodziło właściwemu podejściu do problemu hermeneutycznego. Zastosowano przy interpretacji tekstów biblijnych zewnętrzne, formalne reguły, narażając rzeczywistość Objawienia na ruinę ${ }^{41}$. Tymczasem chodzi tu przede wszystkim o ustosunkowanie się wewnętrzne hermeneuty; chodzi o pewien sposób przyczyniania się od wewnątrz do odsłonięcia się tej rzeczywistości (tj. słowa Bożego). Bo hermeneutyka winna pozwolić sło-

39 Por. WG, 340n oraz Das Wesen des christlichen Glaubens, Zürich, ${ }^{21} 1960,102 \mathrm{n}$ i 243 n.

${ }_{40}$ Por. R. Marlé, dz. cyt., $79 \mathrm{n}$.

41 Por. WG, $320-323$. 
wu Bożemu, utrwalonemu w Biblii, zaktualizować się, okazać swą moc oświeceńczą i przetwarzającą, stać się prawdziwie słowem przy dotarciu do adresata. Hermeneutyka jest ruchem, przez który rzeczywistość sama ujawnia się i osiąga skutecznie swój cel.

Podobnie więc jak Bultmann, przyznaje Ebeling decydującą rolę przy interpretacji kerygmatu biblijnego subiektywnej postawie hermeneuty, postawie mianowicie otwartości i gotowości do decyzji wiary; a również należytemu ,przedrozumieniu” istotnej ,rzeczy” Biblii oraz odpowiednim pytaniom zadawanym tekstowi. Tylko ten - zaznacza on - kto jest już zaszczepiony na rzeczywistości słowa (Bożego), przez kogo i w kim słowo już jakoś się wypowiada, może owocnie praktykować hermeneutykę. Bo jest ona nie tylko przedsięwzięciem podjętym dla zrozumienia języka, ile przede wszystkim poszukiwaniem sensu poprzez język. „S amo słowo ma funkcję hermeneutyczną" ${ }^{42}$. Treścią i przedmiotem hermeneutyki jest wydarzenie słow a (Wortgeschehen) ${ }^{43}$. Wychodzi ona od słowa Bożego, pozwalając mu na autentyczną realizację. A jest przy tym usytuowana w historii, której ruch wyraża. W hermeneutyce teologicznej ma miejsce, według Ebelinga (podzielającego tu opinię Bultmanna) ruch kolisty (circulus hermeneuticus) ${ }^{44}$ : współzależność między istotnym sensem danego tekstu i jego właściwym rozumieniem a osobistym nastawieniem hermeneuty, jego ,przedrozumieniem" owego istotnego sensu tekstu oraz charakterem zadawanych tekstowi pytań.

Kładąc nacisk na egzystencjalny cel i charakter hermeneutyki teologicznej Ebeling twierdzi, że miejscem, gdzie słowo Boże zaświadczone w Biblii rozbrzmiewa, wzywając człowieka do decyzji wiary i gdzie rozstrzyga się jego egzystencja, jest sumienie. Ono jest miejscem konkretnego spotkania z Bogiem, ze światem, z człowiekiem; ono też znajduje się u podstaw odpowiedzialnego działania. ,Z a sadą hermeneuty czną - konkluduje nasz autor - jest człowiek, jako su$\mathrm{mi}$ i $\mathrm{n}$ i e" ${ }^{45}$.

W przeciwstawieniu do indywidualistycznie pojętej hermeneutyki Bultmanna, a zgodnie $z$ tezą Diltheya i Gadamera, uznaje Ebeling tradycję (mianowicie tradycję kościelną, pojętą jako życie wiary) za tło i współczynnik właściwej interpretacji depozytu Objawienia Bożego. Wy. razem tego stanowiska jest $m$. in. jego zolanie o ścisìm związku hermeneutyki z nawiązującym do tradycji przepowiadaniem kościelnym.

Z tego jednak nie powinno, wedle opinii naszego autora, wynikać posiugiwanie się przy interpretacji kerygmatu tajemniczym językiem religijnym, niezrozumiałym dla dzisiejszych ludzi. Skoro hermeneutyka, bę-

42 Por. WG, $333 \mathrm{n}$.

43 Por. WG, 328 i 348.
44 Por. WG, 337

45 Por. WG, 343. 
dąc interpretacją świata wiary, jest równocześnie interpretacją rzeczywistości ludzkiej, historycznej - powinna więc posługiwać się pojęciami i terminologią świecką. Ebeling pozytywnie odnosi się do propozycji Bonhoeffera, aby w teologii i przepowiadaniu kościelnym zastąpić pojęcia religijne świeckimi ${ }^{46}$.

\section{B. Pogląd E. Fuchsa}

Z zapatrywaniem Ebelinga harmonizuje zasadniczo pogląd drugiego, głównego przedstawiciela „nowej” hermeneutyki, założyciela i kierownika Instytutu hermeneutycznego w Magdeburgu, Ernsta Fuchsa ${ }^{47}$. I on również, wychodząc z założeń filozofii języka Heideggera II i Gadamera oraz podzielając na ogół zasady hermeneutyczne Bultmanna - uważa hermeneutykę za naukę o języku, mianowicie o języku wiary, za gramatykę wiary (Sprachlehre des Glaubens). Dla niego też hermeneutyka dotyczy wydarzenia języka wzgl. mowy (Sprachgeschehen, wzgl. Sprachereignis); a właściwie ruchu duchowego, odnoszącego się do tego wydarzenia (Sprachbewegung). W hermeneutyce chodzi, według niego, o ruch czyli proces egzystencjalny przejścia od danych tekstów biblijnych, zawierających ,zobiektywizowane”, przeszłe słowo Boże, które „wydarzylo się" w Jezusie Chrystusie do aktualizacji i zrozumienia tego słowa w konkretnej historycznej sytuacji życiowej danego hermeneuty ${ }^{48}$.

Jest to proces wyrażający się właściwym samozrozumieniem danej osoby i decyzją wiary, wzgl. językiem, czy słowem wiary. Proces ten dochodzi do skutku, według Fuchsa, podzielającego tu stanowisko Ebelinga wzgl. Gadamera, przy interpretowaniu Biblii na tle tradycji kościelnej, czyli życia wiary, w związku z przepowiadaniem kościelnym. Ale przesłanką decydującą o należytej, aktualizującej interpretacji słowa Bożego utajonego w danym tekście Biblii, jest nastawienie i doświadczenie życiowe hermeneuty oraz związane z jego doświadczeniem zadawanie odpowiednich pytań tekstowi ${ }^{49}$.

Ponieważ zaś słowo Boże jest słowem miłości, miłosnym wezwaniem skierowanym do człowieka, dlatego tylko ten, kto przystępując do in-

46 Por. jego rozprawy: Die ,nicht-religiöse Interpretation biblischer Begriffe”, w: WG, 90-160 oraz Dietrich Bonhoeffer, tamże, 294-299.

47 Główne prace Fuchsa dotyczące problemu hermeneutycznego są następujące: Hermeneutik, Bad Cannstatt ${ }^{2} 1958$; Zur Frage nach dem historischen Jesus, Tübingen 1960; Zum hermeneutischen Problem in der Theologie. Die existentiale Interpretation. Ges. Auf. I, Tübingen 1959; Das Neue Testament und das hermeneutische Problem, w: Neuland, t. II, 147-186; Glaube und Erfahrung. Ges. Auf. III, Tübingen 1965, Marburger Hermeneutik, Tübingen 1969; w przedstawieniu poglądu Fuchsa korzystałem z prac: P. Grech, La nuova ermeneutica Fuchs ed Ebeling, w: Esegesi ed ermeneutica, Brescia 1972, 71-90 i Gesù storico e ermeneutica esistenziale, Roma 1973, 97-123 oraz F. Mussner, dz. cyt., 19-21; J. M. Robinson, Neuland, t. II, 61-90.

48 Por. Hermeneutik, $101 \mathrm{n}$; Zum hermeneutischen. Problem in der Theologie, 115.

49 Por. Hermeneutik, 67; Marburger Hermeneutik, 203. 
terpretacji tekstów Pisma św. pojmuje je jako słowo miłującego Boga, może osiągnąc należyte ich zrozumienie. A zarazem może zdobyć właściwe zrozumienie siebie samego, swojej sytuacji i swoich możliwości egzystencjalnych oraz sensu wszelkiej rzeczywistości. Zrealizuje się w nim decyzja wiary i zbawczej miłości., Miłość, stwierdza Fuchs, je st z a s a d h e rmene u t y c z n ą" ${ }^{50}$.

W przeciwieństwie do Bultmanna, który nie przyjmuje ciągłości mię-dzy Jezusem historii a Chrystusem kerygmatu wzgl. wiary i w którego wywodach nie ma miejsca dla działalności Jezusa historii — Fuchs przypisuje owej działalności i przepowiadaniu Jezusa, a zwłaszcza jego śmierci, zasadnicze znaczenie dla wiary chrześcijan. W Jezusie, w jego decyzji egzystencjalnej zaktualizowało się — według tego autora - w szczególny sposób słowo Boże, jako słowo Miłości. Dlatego Jezus jest fundamentem i wzorem wiary. Chrześcijanin spotyka Jezusa w swoim wydarzeniu mowy; odtwarza w nim Jezusowe Sprachgescheben ${ }^{\mathbf{5 1}}$.

\section{KONCEPCJA HERMENEUTYKI TEOLOGICZNEJ E. SCHILLEBEECKXA}

Najbardziej przepojone duchem filozofii egzystencjalnej i zbliżone do zapatrywań twórców ,nowej hermeneutyki” ze strony katolickiej sạ poglądy czołowego dziś teologa holenderskiego E. Schillebeeckxa. Ale charakteryzują się one też pewną oryginalnością ${ }^{52}$.

Przy namiętnym rozstrząsaniu i naświetlaniu problemu hermeneutyki teologicznej i tzw. krytycznej teologii, Schillebeeckx zdaje się podzielać w pełni tezy Heideggera dotyczące struktury ludzkiego bytu i ludzkiego poznania, wzgl. rozumienia rzeczywistości. Opowiada się też zdecydowanie za aktualizującą, egzystencjalną interpretacją orędzia chrześcijańskiego i dogmatów kościelnych ${ }^{53}$. Zaleca wykorzystywanie przy hermeneutyce - poza przyjętymi już narzędziami metody historyczno-krytycznej — również niektórych osiągnięć nowoczesnej analizy językowej: strukturalistycznej, fenomenologicznej, logicznej i zwłaszcza „ontologicznej" (Heideggera i Gadamera) ${ }^{\mathbf{5 4}}$.

Rozpatrując szczegółowo zagadnienie ortodoksyjności danej interpretacji depozytu Objawienia i dogmatów wiary, czyli zgodności wyników tej interpretacji z prawdziwą treścią i sensem Objawienia i wiary podkreśla nasz autor mocno fakt istnienia pluralizmu teologicznego już od samego początku chrześcijaństwa. I wypowiada przy tym sceptyczny

50 Por. Hermeneutik, 78 i 111; Marburger Hermeneutik, 50 i $79-91$.

51 Por. Zur Frage nach dem historischen Jesus, 143 n. i 164.

52 Zagadnienie hermeneutyki teologicznej omawia Schillebeeckx w rozprawach wydanych zbiorowo pt. Glaubensinterpretation. Beiträge zu einer hermeneutischen und kritischen Theologie, Mainz 1971.

53 Por. dz. cyt., 83-108.

54 Tamże, $9-47$. 
wniosek, iż ,wśród chrześcijan czysto teoretyczna weryfikacja ortodoksji czy też heterodoksji jest zgoła niemożliwa" 55. Wysuwa więc pragmatyczną tezę, że kryterium autentyczności i prawdziwości rozumienia oraz wykładni orędzia chrześcijańskiego i dogmatów wiary jest należyta praktyka życiowa: ortopraksja ${ }^{56}$. W związku zaś z tym swoim twierdzeniem przychyla się zasadniczo do stanowiska przedstawicieli ,Frankfurckiej Szkoły” socjologicznej, twórców tzw. „Krytycznej teorii społeczeństwa" (kritische Gesellschaftstheorie), zwłaszcza J. Habermasa. Uważa ,krytyczną teorię” za umiejętność pomocniczą teologii ${ }^{57}$. A teologię (utożsamianą przez siebie z hermeneutyką teologiczną) uważa za ,krytyczną teorię praktyki płynącej z wiary" 58 wzgl. za ,krytyczną samoświadomość płynącej z wiary praktyki w świecie i w Kościele" 59 .

Podobne jak Schillebeeckx zapatrywania $w$ kwestii roli praktyki (,,ortopraksji”) w hermeneutyce teologicznej, wzgl. w teologii głoszą: J. Metz, teoretyk ,teologii politycznej” oraz zwolennicy ruchu tzw. „krytycznego katolicyzmu”; oni też zdają się pojmować teologię jako ,krytyczną teorię" społeczeństwa wedle modelu Szkoły Frankfurckiej.

\section{HERMENEUTYKA SYMBOLISTYCZNA P. TILLICHA I P. RICOEURA}

Do filozofii egzystencjalnej Heideggera i zarazem do koncepcji hermeneutycznej Bultmanna nawiązują, przy rozstrzyganiu problemu interpretacji kerygmatu biblijnego, poglądy dwóch wybitnych myślicieli współczesnych: teologa niemieckiego (działającego przez długie lata na wygnaniu w Stanach Zjednoczonych), P. Tillicha i filozofa-religioznawcy francuskiego, P. Ricoeura. Obydwaj oni uważają język religijny Biblii za język symboliczny, względnie mitologiczny. I obydwaj kładą nacisk na egzystencjalny sens kerygmatu biblijnego. Ale istnieje pewna rozbieżność w ich zapatrywaniach na charakter symbolu religijnego oraz na sposób interpretowania go.

P. Tillich uważa symbol religijny za rezultat pierwotnego doświadczenia „Swiętego”, czyli spotkania z ,Bezwarunkowym” (tj. z Bogiem) utrwalający to doświadczenie i stanowiący wyraz świadomości i postawy religijnej ${ }^{60}$. S y m b ol — według jego określenia — jest $\mathrm{z} n$ aki e m

55 Por. tamże, 57.

56 Por. tamże, 63-75.

57 Por. tamże, $150-165$.

58 Por. tamże, 159.

59 Por. tamże, 171.

60 Pogląd Tillicha omawia B. Mondin w dz. cyt., 333-387; oraz w pracy: Paul Tillich e la trasmitizzazione del cristianesimo, Torino 1967; Anna Morawska, Paul Tillich, w: „Znak”, 17 (1965) 986-1010. Tillich uważał za najważniejsze swoje zadanie, jako teologa, interpretację symbolów religijnych tak, aby były zrozumiałe dla ludzi świeckich. $\mathrm{Na}$ temat symbolu religijnego napisał szereg rozpraw; por. B. Mondin, Il problema, 133n. 
wskazującym na rzeczywistość poza sobą i mającym pewne uczestnictwo w tej rzeczywistości ${ }^{61}$. W przeciwieństwie do znaków konwencjonalnych, będących dowolnymi, sztucznymi tworami, symbole rodzą się spontanicznie z doświadczenia religijnego, w którym „Bezwarunkowe” wkracza w egzystencję człowieka. Symbole i mity religijne pozostają w ścisłym związku z najbardziej zasadniczymi doznaniami egzystencji ludzkiej, np. z poczuciem trwogi egzystencjalnej, zagrożenia, zagubienia w świecie itp. Dają one odpowiedź na dręczące pytania człowieka związane z tymi doznaniami. Język symboliczny jest niezbędny dla określenia stosunku Boga (,Bezwarunkowego") do człowieka oraz żywotnego stosunku człowieka do Boga; jest jedynym językiem dozwalającym mówić należycie o Bogu ${ }^{62}$. Ale symbole trzeba rozumieć jako symbole. Gdyby rozumiało się je i tłumaczyło literalnie, prowadziłoby to do bałwochwalstwa ${ }^{63}$.

Symbole religijne mogą - według Tillicha - zatracić swoją wartość i swój sens z chwilą utracenia mocy wywoływania na nowo doświadczenia „Swiętego” w łonie społeczności religijnej. Dzieje się to wówczas, gdy zmienia się radykalnie sytuacja kulturowa i mentalność ludzka. I tak np. w obecnej, gruntownie zmienionej sytuacji kulturowej utraciły swą wartość i swój sens wszystkie symbole o wydźwięku nadprzyrodzonym. Bo dla współczesnych ludzi istnieje tylko jedna sfera rzeczywistości, w której i Bóg się znajduje, jako jej fundament ${ }^{64}$. Toteż należałoby obecnie dawne symboliczne określenia zastąpić nowymi, np. zamiast określenia ,byt najwyższy” na oznaczenie Boga, należałoby używać raczej wyrażeń: „fundament bytu”, czy ,głębia bytu”, lub „moc bytu”, lub „samo istnienie”; a znów na oznaczenie Chrystusa (którego autor uważa za centralny, najdoskonalszy symbol Boga) zamiast określenia ,Syn Boży” należałoby posługiwać się określeniem ,nowy byt” 65 .

Tego rodzaju demityzacja, czyli zastąpienie dawniejszych wyrażen symbolicznych nowymi, bardziej zrozumiałymi dla współczesnego człowieka i skuteczniejszymi przez to w dziedzinie wiary i życia religijnego, różni się zasadniczo od postulowanej przez Bultmanna i zwolenników „,nowej” hermeneutyki demitologizacji kerygmatu chrześcijańskiego. Ale, gdy chodzi o dziedzinę nauki, wzgl. krytycznej świadomości naukowej, Tillich podziela stanowisko Bultmanna co do potrzeby demitologizacji Biblii, choć ta demitologizacja spowodowana krytyką rozumową przyczynia się do ,załamania" (Zerbrechen) symbolu, wzgl. mitu.

61 Por. B. Mondin, dz. cyt., 337n.

62 Por. tamże, 342 n.

63 Por. tamże, $350 \mathrm{n}$.

64 Por. tamże, 353-357.

65 Por. tamże, 357-372. 
Podobnie jak P. Tillich zainteresowany jest i - można by powiedzieć - zaabsorbowany problemem hermeneutycznym religiolog francuski, P. Ricoeur. Bierze on od szeregu lat żywy udział w dociekaniach i dyskusjach dotyczących tego problemu. Szczególnie zaś ujawnił swoje zainteresowanie dla zagadnienia hermeneutyki biblijnej w czasie Kongresu Katolickiego Stowarzyszenia francuskiego dla studiów nad Biblią (A. C. F.E. B.), odbytego we wrześniu 1969 r. w Chantilly 66.

Według Ricoeura hermeneutyka jest teorią interpretacji symboli ${ }^{6 \pi}$, m. in. symboli religijnych. Symbole mają, jego zdaniem, podwójne, nierozdzielne od siebie znaczenie: dosłowne i przenośne. Są znakami wskazującymi na coś poza sobą i mającymi pewną odnośnię do tego czegoś. O uczestnictwie symboli w rzeczywistości, na którą wskazują i do której pozostają w pewnej odnośni nic autor ten (w przeciwieństwie do Tillicha) nie mówi 68 .

Symbole, wzgl. mity pełnią, według Ricoeura, niezastąpioną rolę gnozeologiczną. Przekazują one naszej świadomości treści, które nie mogłybyby być wyrażone innymi środkami. Język symboliczny jest językiem informującym o podstawowych sprawach bytu; skierowuje naszą uwage i świadomość do sfery, gdzie człowiek dostrzega źródło swego istnienia i swej wartości. W symbolach i mitach religijnych wyrażona została istotna wiedza o naszej egzystencji i jej sensie ${ }^{69}$.

Przy interpretacji symboli i mitów religijnych zaleca Ricoeur stosowanie metody anamnezy historycznej, uwzględniającej zarówno dane analizy egzystencjalnej Heideggera jak i analizy językowej (strukturalizmu) oraz historii religii, psychologii i psychoanalizy ${ }^{\mathbf{7 0}}$.

Oto w szkicowym zarysie bardziej oryginalne i głośne koncepcje, wyznaczające nowe kierunki współczesnej hermeneutyki teologicznej. Dużo się o nich obecnie dyskutuje i pisze, zwłaszcza o koncepcji R. Bultmanna oraz twórców „nowej hermeneutyki”. Oceny są zróżnicowane.

66 Akta tego Kongresu zostały ogłoszone pt. Exégèse et herméneutique, Paris 1971. Zamieszczone tu są rozprawy Ricoeura pt. Du conflit à la convergence des méthodes en exégèse biblique, 35-53 oraz Sur l'exégèse de Genèse 1, 1-2, 67-84 i Esquisse de conclusion, 285-296. O różnych rozprawach Ricoeura dotyczących problemu hermeneutycznego oraz o licznych studiach omawiających poglądy Ricoeura, zob. B. Mondin, dz. cyt., 480-495 i Fr. Marton, L'interpretazione nel pensiero di Paul Ricoeur, w: Esegesi ed ermeneutica, 91-107; por. też art. J. Tischnera, Perspektywy hermeneutyki, w: „Znak”, 23 (1971) 145-172 oraz E. Bieńkowskiej, Paul Ricoeur, w: ,Znak”, 25 (1973) 260-266.

"Z7 Por. jego rozprawę: De l'interprétation. Essai sur Freud, Paris 1965, cyt. przez B. Mondin, dz. cyt., 480 .

68 B. Mondin, dz. cyt., 484.

69 Tamże, 487-491.

70 Tamże, 494; por. też rozprawę Ricoeura, Du conflit à la convergence des méthodes en exégèse biblique, w: Exégêse et herméneutique, 35-53. 
Nie jest moim zadaniem (i nie jestem w stanie) przeprowadzić obecnie dokładniejszą ocenę tych koncepcji. Zaznaczę więc tylko, że w kołach teologów protestanckich zyskały aplauz i licznych zwolenników zarówno niektóre nurty sekularyzacyjne, nawiązujące do systemów analizy językowej, jak również koncepcje oparte na egzystencjaliźmie Heideggera. Ale tak jedne jak i drugie stały się też przedmiotem zakwestionowania ze strony niektórych wybitnych teologów protestanckich.

Ogół niemal autorów katolickich, rozpatrujących zagadnienie hermeneutyki, ocenia krytycznie radykalne tezy tak rzeczników świeckiej interpretacji chrystianizmu, zwłaszcza zwolenników ,teologii śmierci Boga” (których stanowisko uważa np. B. Mondin za absurdalne), jak i Bultmanna oraz kontynuatorów jego myśli, twórców „nowej hermeneutyki”, czy Schillebeeckxa ${ }^{71}$.

Przy tym jednak pełną aprobatą cieszy się intencja i dążność teoretyków i zwolenników omówionych koncepcji do przybliżenia mentalności współczesnych ludzi orędzia chrześcijańskiego przez oczyszczanie pojęć religijnych $z$ nalotów antropomorfistycznych oraz akcentowanie sensu egzystencjalnego i życiowej wartości tego orędzia; do uwiarygodnienia go dzisiejszym ludziom, oszołomionym zdobyczami nauki i techniki, zaufanym w sobie i oddalającym się coraz powszechniej od Boga i religii.

Z uznaniem również podkreślają ci teologowie fakt, że w Piśmie św. widzą twórcy i zwolennicy tych nowoczesnych koncepcji hermeneutycznych utajone pod osłoną ludzkich sformułowań zbawcze słowo Boże, skierowane do człowieka, odsłaniające mu istotny sens jego życia ora całej historii i wzywające go do decyzji wiary oraz do autentycznej egzystencji w duchu Ewangelii Chrystusowej.

Jako trafne ocenia się dalej założenie o ważności dla należytego rozumienia chrześcijańskiego orędzia, pozytywnego nastawienia hermeneuty, jego otwartości i gotowości na danie posłuchu wezwaniu słowa Bożego, jako słowa miłości i zbawienia.

Pozytywnie ocenia się tė̇ opinię rzeczników, ,nowej hermeneutyki” o pomocniczej roli tradycji przy interpretacji Biblii, czy artykułów wiary oraz twierdzenia teoretyków symbolizmu biblijnego o głębokim sensie i walorze symboli czy mitów religijnych.

71 Wśród olbrzymiej ilości studiów, w których autorzy katoliccy podają krytyczną ocenę omówionych koncepcji hermeneutycznych, zasługują na szczególniejszą uwagę prace zebrane w Vt. KM, a również: L. Marlé Bultmann et l'interprétation du Nouveau Testament, Paris 1968; L. Malevez, Le message chrétien et le mythe - La théologie de Rudolph Bultmann, Paris 1954; G. Hasenhütl, der Glaubensvollzug Eine Begegnung mit R. Bultmann aus katholischem Glaubensverständnis, Roma 1962; B. Mondin, dz. cyt., w którym, po omówieniu poglądów poszczególnych autorów, podane są uwagi krytyczne; studia zebrane w: Esegesi ed ermeneutica, w których również podane są oceny krytyczne. 
Ale, aprobując powyższe założenia hermeneutyczne i niektóre dalsze, szczegółowe tezy twórców omawianych koncepcji, wytaczają autorzy katoliccy nie bez słuszności poważne zastrzeżenia i zarzuty przeciwko tym koncepcjom. Przede wszystkim kwestionują ich podstawowe założenia filozoficzne, jako wykluczające wszelką metafizykę, ujmujące zbyt ciasno i jednostronnie egzystencję ludzką, zacierające całkowicie (Bultmann, Fuchs, Ebeling i i.) rozdział pomiędzy przedmiotem poznania a podmiotem poznającym i podważające tym samym obiektywność poznania religijnego.

Zarzut subiektywizmu i dowolnej racjonalizacji depozytu Objawienia kierowany jest słusznie tak przeciwko Bultmannowi jak i przeciw teoretykom ,nowej hermeneutyki”, Tillichowi czy Ricoeurowi. Zarzut ten pozostaje w związku z postulatem demitologizacji tekstów biblijnych oraz z apriorycznym zaprzeczaniem realizmu wszelkich faktów, czy wydarzeń nadprzyrodzonych.

Katoliccy teologowie przyznają również, że w Piśmie św. mamy do czynienia $\mathrm{z}$ przedawnionym, mitycznym ujęciem obrazu świata oraz z wielu przenośniami i symbolami. Dlatego i oni dopuszczają pewnego rodzaju demitologizację niektórych tekstów biblijnych. Ale sprzeciwiają się, jako nieuzasadnionemu twierdzeniu, iż język biblijny jest w całości językiem symbolu czy mitu zawierającym tylko pewne przenośnie, zaszyfrowane znaczenie egzystencjalne, które można odkryć i zrozumieć przy zastosowaniu nowoczesnych metod, w oparciu o dane analizy językowej, czy egzystencjalnej, psychologii czy psychoanalizy.

Gdy chodzi specjalnie o ocenę oryginalnego aspektu koncepcji Schillebeeckxa, tj. jego praktycyzmu hermeneutycznego, czyli uznania należytej praktyki, płynącej z wiary (,ortopraksji”) za istotne kryterium prawdziwości danej interpretacji Biblii, czy artykułów wiary - ocena ta jest negatywna. Bo stanowisko tego rodzaju, zbliżone wielce do stanowiska twórców „krytycznej teorii społeczeństwa” ze Szkoły Frankfurckiej, godzi w należyte pojęcie prawdy i zdaje się być wyrazem sceptycznego irracjonalizmu w teologii 72 .

Poważne zastrzeżenia wysuwają też teologowie katoliccy przeciwko koncepcji symbolistów: Tillicha i Ricoeura ${ }^{73}$.

72 Por. L. Scheffczyk, Glaube und kritisches Bewusstsein, Orthodoxie oder Orthopraxie? Zu einem Buch von Edward Schillebeeckx, w: "Christ in der Gegenwart", 24 (1973) 382. Autor ten pisze tu $\mathrm{m}$. in.: ,So rückhaltlos und gedankenscharf ist bislang die Forderung nach Einbeziehung der modernen Verhaltenswissenschaften und insbesondere der ,kritischen Theorie" der Frankfurter Schule in die teologische Hermeneutik noch nicht erhoben worden. Hier liegt freilich auch das zutiefst Problematische dieses Werkes".

${ }_{73}$ Por. np. B. Mondin, dz. cyt., 495; R. Lapointe, w art. cyt., 135-141 podkreśla raczej dodatnie strony koncepcji symbolistów. 